\title{
International Trade in Manufacturing: A Review and Bibliometric Analysis (1996-2020)
}

\author{
Jing Jiang, Linchi Qu \\ School of Economics \& Management, Shanghai Maritime University, Shanghai, China \\ Email: Christinejiang2@hotmail.com
}

How to cite this paper: Jiang, J., \& Qu, L. C. (2020). International Trade in Manufacturing: A Review and Bibliometric Analysis (1996-2020). Modern Economy, 11, 1064-1082.

https://doi.org/10.4236/me.2020.115080

Received: April 12, 2020

Accepted: May 25, 2020

Published: May 28, 2020

Copyright (อ 2020 by author(s) and Scientific Research Publishing Inc. This work is licensed under the Creative Commons Attribution International License (CC BY 4.0).

http://creativecommons.org/licenses/by/4.0/ (c) (i) Open Access

\begin{abstract}
Manufacturing is the engine of the world economy. Under complicated and volatile international situation, it is worth thinking about where the world manufacturing trade pattern will go. Therefore, it is necessary to sort out the trade-related research of manufacturing trade. This paper systematically reviewed the research on international trade in manufacturing through qualitative and quantitative research methods, which made up for the deficiency of the existing reviews in this field. This paper used CiteSpace software to carry out a bibliometric analysis of 1027 documents from the Web of Science (1996-2020). The study found that authoritative journals in this field are concentrated in the economic field and the quality of publications is high. The cooperation between scholars is not close, and papers are mainly distributed in North America, Europe, Asia and Australia. The research focus has shifted from international trade, productivity and impact to performance, China, innovation, etc. International trade in manufacturing was subdivided into eight major research fields. According to the burst-detection, national trade markups, input and output analysis, improvement of quality, and export market will become future development trends.
\end{abstract}

\section{Keywords}

Manufacturing, International Trade, Bibliometrics, Evolution, Hotspot, Emerging Trends

\section{Introduction}

Manufacturing is considered as the driving force of economic growth, structural changes and catch-up, and its impact on the national economy is far-reaching and extensive (Naudé \& Szirmai, 2012). The trade friction launched by the United States in 2018 was aimed at China, to curb the pace of transforming 
China from a manufacturer of quantity to one of qualities and maintaining its leading position in the high-end manufacturing field (USTR, 2018). As the major importer and exporter in the world, the trade conflict between China and the United States inevitably had a significant impact on the overall world trade pattern, with the manufacturing stand in the breach. Therefore, manufacturing trade has once again become an increasingly active research hotspot, with various disciplines coexisting.

First of all, many scholars pay attention to the effects of trade policy formulation and implementation under globalization. Nelson believed that drastic changes in US trade policy would pose a danger to the survival of the free trade system (Nelson, 2019). Sanchez reviewed the development of China's trade policy and put forward a series of challenges related to trade policy that China faces (Sanchez-Fung, 2016). Zhang summarized trade policies in China from 2014 to 2016, mainly covered the "the Belt and Road Initiative", trade facilitation policy, and promotion of cross-border electronic commerce (Zhang, 2017). Chen discussed the trade policies of Singapore and practices and pointed out the problems and challenges faced, put forward suggestions of other small open economies (Chen \& Shao, 2017). Secondly, many scholars make systematic review of a branch of international trade in the manufacturing industry. Orden supervised the World Trade Organization's performance in regulating agricultural and food trade, and proposes a regulatory roadmap (Orden \& Roberts, 2007). Vaubourg stressed the complexity of the relationship between finance and trade. On the one hand, finance was driven by trade patterns; on the other hand, there was institutional interaction between finance and trade reform (Vaubourg, 2016). Also, many scholars conduct useful discussions on the relationship between international trade and the environment. The research of Cherniwchan attracted wide attention in the academic circle. He introduced a new method to link emission changes with production activities at the factory, enterprise, industry, and national levels (Cherniwchan, Copeland, \& Taylor, 2017). Frei was concerned about global green energy trading, and believed that the channels and products of green trading would affect the green energy market (Frei, Loder, \& Bening, 2018).

After nearly 25 years of development, manufacturing trade has formed a relatively rich knowledge reserve and theoretical contributions. However, at present, the reviews in this field mainly adopt qualitative methods and rely on the framework constructed subjectively by the authors to sort out the existing literature. Therefore, understanding and grasping the history, current situation and trend of international trade research are of practical significance for further understanding of international trade research in the manufacturing and discovering new research issues, providing references for scientific research topics, academic innovation, and development direction of international trade in the manufacturing.

Compared with the traditional qualitative review, it is more comprehensively, intuitively and objectively based on knowledge map to quantitatively measure 
and visualize the literature. Therefore, this paper used CiteSpace, a scientific visualization software, to make an overall bibliometric analysis of international trade in the manufacturing, to review and track the evolution of hotspots and the progress of knowledge structure of international trade in manufacturing, and to look forward to the development trends of this field.

\section{Methodology}

\subsection{Research Methods}

This paper adopted the method of scientific knowledge map. First of all, based on Citespace software, the basic statistical analysis of core journals, core authors, core regions and discipline distribution of international trade in manufacturing were realized. the basic situations of manufacturing international trade research was described. After that, a co-occurrence network analysis of keywords in the research literature was made and the research hotspots and evolution process of international trade in manufacturing were explored. The keyword co-occurrence network refers to counting the number of occurrences of a group of words in the same group of documents in pairs and measuring their affinity and affinity through this co-occurrence number. At present, the common co-occurrence visualization method was relational network visualization. Finally, based on the co-cited knowledge map of literature, the mainstream sub-areas in the international trade of manufacturing were investigated. Co-citation analysis means that if the two documents appear together in the bibliography of the third cited document, the two documents form a co-citation relationship. Science mapping is an important bibliometrics method. It presents the structure, regulation and distribution of scientific knowledge in the field of international trade in manufacturing by visual means, and explores the development of the subject knowledge field and its research hotspots, frontiers and trends.

\subsection{Date Source and Processing}

This paper focused on the evolution process and structure of international trade in manufacturing. The research references were all from the core set of Web of Science in the database of SCI and SSCI, which included the most influential core academic journals in social science and other fields and were recognized as authoritative citation index databases worldwide. Duplicate checking of the literature records was carried out, 1027 literature records were totally obtained, time parameter was set as 1996-2020 and Year per Slice as 4, first 50\% high-frequency nodes in each period were used, and setting is shown in Figure 1 and more search details are listed in Table 1.

\section{Basic Statistical Analysis of International Trade in Manufacturing}

\subsection{Yearly Quantitative Distribution of Literature}

Bibliometrics refers to the use of quantitative research methods such as statistics 


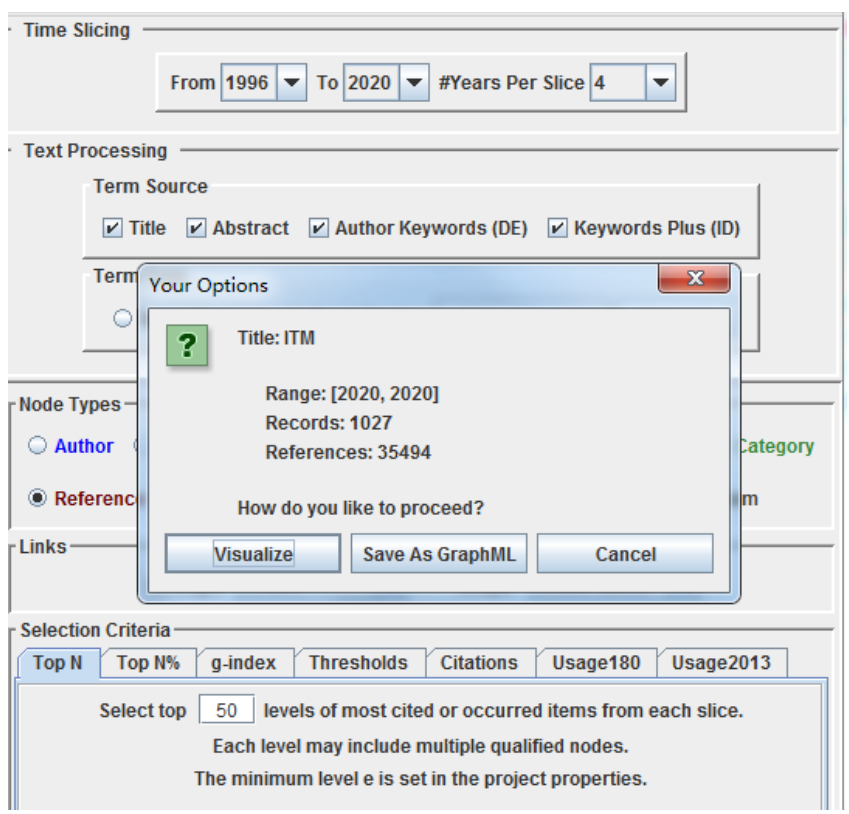

Figure 1. Setting of citespace.

Table 1. Summary of searching for details.

\begin{tabular}{cc}
\hline Search settings & Content \\
\hline Database & Core Collection-SCI + SSCI \\
Searching term & international trade + manufacturing \\
Literature & article; review \\
Time span & $1996-2020$ \\
Searching time & $20,200,419$ \\
Results & 1027 \\
\hline
\end{tabular}

to analyze the quantitative relationship and evolution path of literature, which can reveal the research status and development process of discipline. Therefore, this paper made statistics on the 1027 documents of international trade in manufacturing, as shown in Figure 2. On the whole, the total number of articles published in this field was increasing year by year: it could be divided into two stages: the number of articles published before 2011 was small and the growth rate was slow, and the relevant research in this field was tepid; After 2012, the number of articles increased significantly and at a faster rate. The research in this field heated up sharply and reached a peak (142 articles) in 2018. After that, the number of published articles decreased slightly but remained relatively high. The above showed that the research on the application of international trade in manufacturing had a relatively small and steady increase from 1996 to 2011, and the research in this field was in the brewing period. From 2011 to 2018, the number of articles published increased gradually, and research in this field has become a research hotspot, which has attracted more and more attention from scholars. 


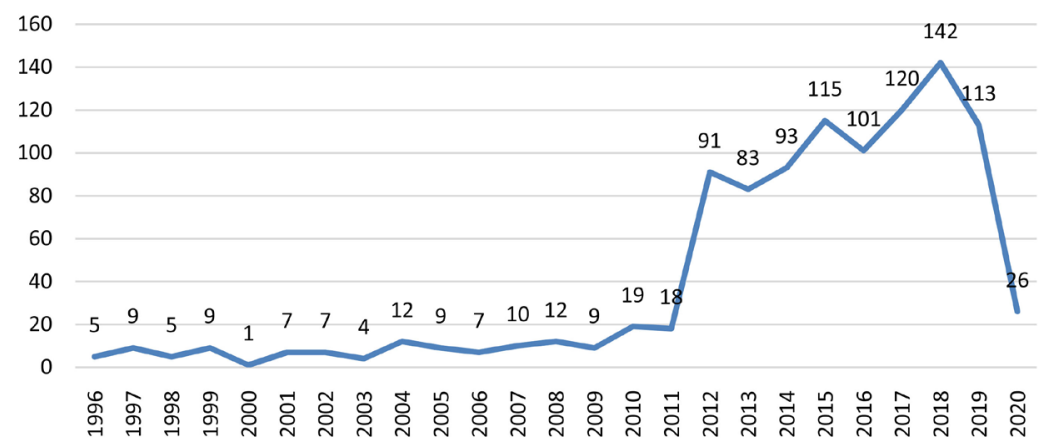

Figure 2. Number of articles in manufacturing in the field of international trade (1996-2020).

\subsection{Journals Distribution}

Table 2 lists the highly cited core journals of international trade in manufacturing from 1996 to 2020, mainly concentrated in the economic field, accounting for $42 \%$ of the total number of published papers. It indicated that the journals of trade-related research documents in manufacturing were relatively concentrated. The impact factors of the top 10 journals were all above 1 , and the average impact factor was more than 5 , which present that many authoritative academic journals were interested in this field. The impact factor refers to the ratio of the total number of citations of papers published by the evaluated journal in the first two years to the total number of papers published by the journal in these two years (Garfield, 2006). Strong manufacturing helps to improve the quality of employment, strengthen its international standing and promote sustained economic prosperity. As can be seen from Table 2, the number of articles published by American Economic Review and Journal of International Economics were more than 400, belonging to the most influential journals, while the influence of other journals was not much different.

\subsection{Analysis of Core Authors}

The number of articles is the performance of researchers' productivity in a certain research field. CiteSpace was used to analyze the author's network of international trade in manufacturing, and core authors who had made outstanding contributions in this field were discovered (Figure 3). The high number of articles indicates a high output in the field. In Figure 3, there are many and scattered nodes, and the number of nodes connected is small. This illustrated that the research of international trade in the manufacturing was relatively scattered, and the links between academic communication and scientific research were not closely related. Individuals and small groups were the main contributors in this filed. Among them, Professor Sai Liang, the Chinese scholar, ranked first with 8 articles.

\subsection{Space-Distribution}

Table 3 lists the main countries and research institutions of international trade 


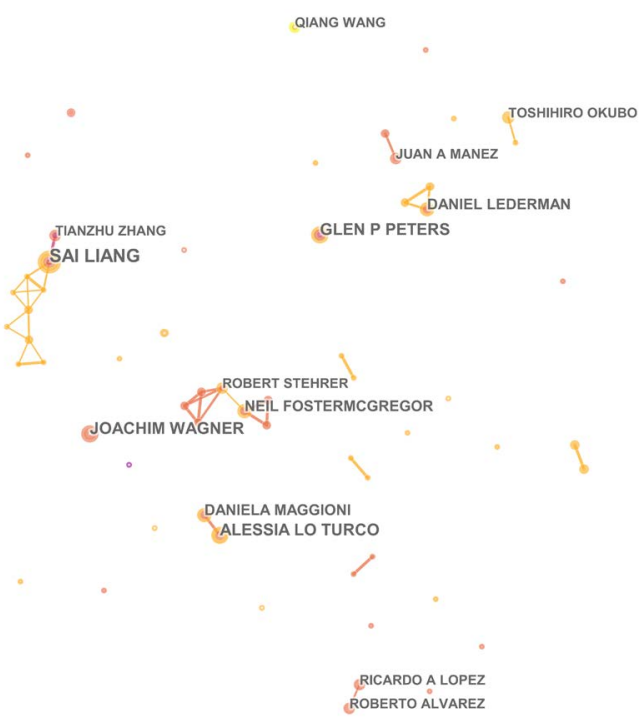

Figure 3. The network of main authors.

Table 2. High cited journals in international trade of manufacturing (Top 10).

\begin{tabular}{ccccc}
\hline Ranking & Count & Year & Cited Journal & 2018 impact factor \\
\hline 1 & 533 & 2004 & American Economic Review & 4.097 \\
2 & 496 & 2004 & Journal of International Economics & 2.216 \\
3 & 397 & 2004 & Quarterly Journal of Economics & 11.775 \\
4 & 382 & 2004 & Review of Economics and Statistics & 3.636 \\
5 & 370 & 2004 & Econometrica & 4.281 \\
6 & 295 & 2008 & Review of Economic Studies & 4.767 \\
7 & 255 & 2005 & Journal of Development Economics & 2.855 \\
8 & 255 & 2005 & Journal of Political Economy & 6.342 \\
9 & 248 & 2008 & World Economy & 1.088 \\
10 & 238 & 2002 & Economic Journal & 2.926 \\
\hline
\end{tabular}

Table 3. The lists of countries and institutions (Top 10).

\begin{tabular}{ccccc}
\hline Ranking & Count & Countries & Count & Institutions \\
\hline 1 & 296 & USA & 31 & NBER \\
2 & 152 & PEOPLES R CHINA & 21 & Chinese Acad Sci \\
3 & 115 & ENGLAND & 21 & World Bank \\
4 & 69 & GERMANY & 14 & Tsinghua Univ \\
5 & 68 & ITALY & 12 & CEPR \\
6 & 48 & CANADA & 10 & Univ Groningen \\
7 & 45 & SPAIN & 10 & Beijing Normal Univ \\
8 & 44 & FRANCE & 10 & Univ Cambridge \\
9 & 42 & AUSTRALIA & 10 & Univ Nottingham \\
10 & 36 & JAPAN & 10 & Katholieke Univ Leuven \\
\hline
\end{tabular}


in manufacturing. The number of documents indicated the research level and contribution of different countries or scientific institutions. The core regions of researching were distributed in North America, Europe, Asia and Australia (Table 3). First of all, the United States topped the list with 296 articles, accounting for about $22 \%$ of the total number of articles, of which the Center for Economic and Policy Research was the main institutions in manufacturing international trade. Secondly, representative Asian countries with large numbers of published articles were China, with 152 articles. The Chinese Academy of Sciences, Tsinghua University and Beijing Normal University were respectively the top 10 research institutions with a high number of published articles. Research on manufacturing trade in Europe was concentrated in developed countries such as Britain, Netherlands and Belgium. The Bureau of International Economic Research of the UK was the world's core research institution, ranking first with 31 articles. Cambridge University, Nottingham University, Groningen University in the Netherlands and Katholieke in Belgium were also important researching institutions for manufacturing trade in Europe.

\subsection{Discipline Distribution}

Table 4 shows the distribution of discipline attributes of international trade in manufacturing in the past 25 years, mainly concentrated in business and economics, ,because international trade in manufacturing mainly involves industry and enterprise-level research. Then came economics, environmental sciences \& ecology, engineering, etc. From the time distribution, we can find that the discipline distribution of international trade in manufacturing has shifted from the earliest in subject of business and economics to recent international relations and business. The data proved that the international trade in manufacturing indicated a trend of interdisciplinary development.

Table 4. Discipline distribution (Top 10).

\begin{tabular}{|c|c|c|c|}
\hline Ranking & Count & Year & WoS Categories \\
\hline 1 & 652 & 1996 & Business \& Economics \\
\hline 2 & 575 & 1997 & Economics \\
\hline 3 & 170 & 1997 & Environmental Sciences \& Ecology \\
\hline 4 & 129 & 1997 & Environmental Sciences \\
\hline 5 & 112 & 1996 & Engineering \\
\hline 6 & 103 & 2012 & International Relations \\
\hline 7 & 87 & 1997 & Environmental Studies \\
\hline 8 & 68 & 1996 & Management \\
\hline 9 & 60 & 2012 & Business \\
\hline 10 & 59 & 1998 & Science \& Technology - Other Topics \\
\hline
\end{tabular}




\section{Analysis of the Evolution Path on International Trade in Manufacturing}

Table 5 lists the most frequently keywords given by authors and indexers to the records. Keywords are a highly concise and concentrated summary of the whole research topic, representing knowledge points and research hotspots in a certain field. The co-occurrence frequency of keywords refers to the number of times that a group of words appears in the same group of documents. Its function is to analyze the internal relationship of an academic field and reveal the frontiers of research within it. International trade and trade were the most frequented keywords in manufacturing international trade, reflecting the research issues in this field. The following were productivity and impact, and the 7th to 9th were performance, firm and industry, indicated that the international trade in manufacturing took firms, organizations or industries as research objects to explore how to achieve higher performance. Scholars were more interested in manufacturing exports and remained optimistic about trade expectations, so growth was also a high-frequency word. More scholars began to pay attention to manufacturing in China, and globalization was also a prominent feature of manufacturing trade. Building models were the main research methods, which focused on technology and emphasized the importance of innovation. In recent years, the relationship between foreign direct investment and international trade had also become a research hotspot.

To better understand the evolution paths of research hotspots of international trade in manufacturing and identify research frontier areas, this paper employed

Table 5. The lists of high frequency keywords (top 15).

\begin{tabular}{|c|c|c|c|}
\hline Ranking & Count & Year & Keywords \\
\hline 1 & 465 & 1997 & International trade \\
\hline 2 & 170 & 2001 & trade \\
\hline 3 & 163 & 2010 & productivity \\
\hline 4 & 132 & 2008 & impact \\
\hline 5 & 123 & 2005 & growth \\
\hline 6 & 121 & 2008 & export \\
\hline 7 & 93 & 2012 & performance \\
\hline 8 & 84 & 2012 & china \\
\hline 9 & 81 & 2004 & firm \\
\hline 10 & 74 & 2007 & industry \\
\hline 11 & 68 & 2012 & innovation \\
\hline 12 & 68 & 1996 & model \\
\hline 13 & 63 & 2004 & technology \\
\hline 14 & 61 & 2010 & globalization \\
\hline 15 & 59 & 2012 & foreign direct investment \\
\hline
\end{tabular}


the form of Timezone to explore the process of keywords correlation (time level) and evolution of knowledge. From 1996 to 2020, there were 119 keywords in the literature on international trade in manufacturing, with a total frequency of 3234. In different periods, the high-frequency keywords for international trade in manufacturing are shown in Figure 4. The research focuses on scholars in different stages that were diverse, which were divided into three stages according to the time slots. The size of the font indicates the frequency of occurrence, i.e. the bigger the font, the higher the frequency of keywords occurrence.

The first stage (1996-2003): the new research introduced new objects and new phenomena. In this stage, there were fewer keywords and fewer articles. The average word frequency of more than 10 keywords reached 77, and research hotspots were relatively concentrated. International trade and trade were mainly discussed from the macro level. The construction and evaluation model was the main quantitative method. The traditional manufacturing power, the United States, still attracted many scholars' attention. The manufacturing industry was taken as the research object, emphasizing the importance of site selection and international cooperation. The hotspots at this stage reflected a typical research paradigm, that was, starting from the theoretical definition and ending in the design and inspection of research parties.

The second stage (2004-2011): the number of publications increased significantly, with the highest frequency of keywords being 163, and the average frequency of keywords appearing more than 10 times was 46 , and research hotspots became loose. Scholars began to try and explore a series of techniques to solve problems. Focused on the improvement of productivity, paid attention to the impact and growth of international trade in manufacturing, and started from the level of enterprises or industries. The technology was the core of international trade in manufacturing, and globalization was the trend of international trade.

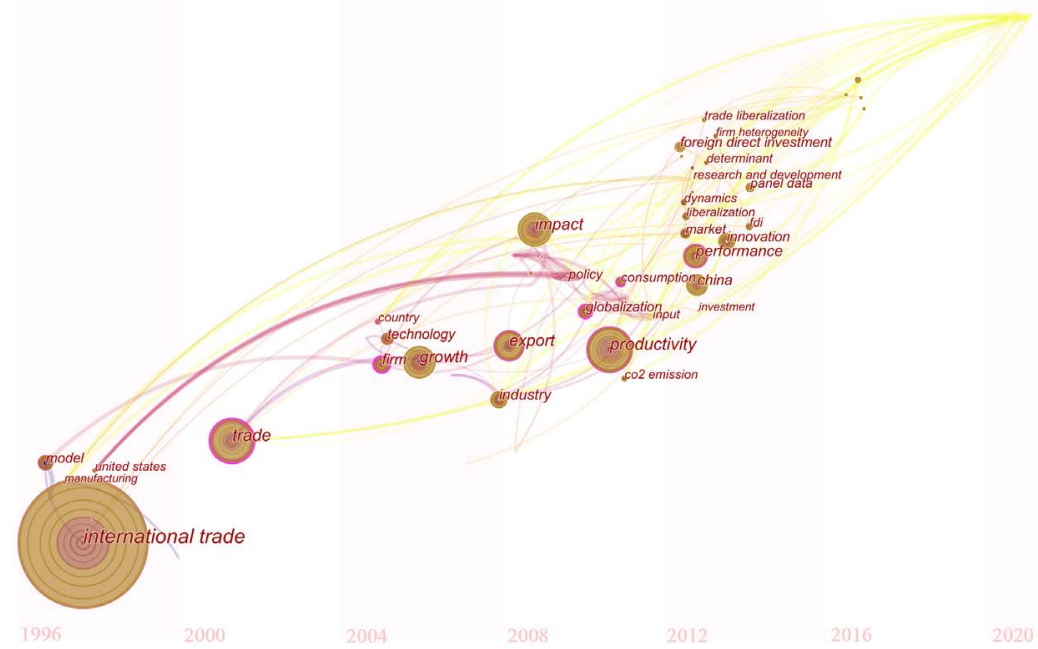

Figure 4. Keywords co-occurrence network of international trade in manufacturing (Timezone). 
In addition to the economy and society, scholars began to pay attention to ecology, such as carbon dioxide emissions and pollution, etc. The above hotspots illustrated that the research in this field was beginning to be more detailed, and was no longer being discussed under the macro concept. More levels and richer topics were put forward around the international trade in manufacturing.

The third stage (2012-present): the number of articles in this stage increased an explosive trend, with the highest frequency of keywords being 93, and the average word frequency of keywords more than 10 times were 32. The research hotspots were quite loose and diversified. Compared with the second stage, the perspective of scholars changed, especially after the financial crisis, more scholars paid attention to the performance of enterprises. China gradually became a popular research issue. Innovation promoted the development of science and technology. Enterprises deepened its research and development. The relationship between International trade and foreign direct investment were widely discussed. Panel data became the main type of data sources, input-output analysis acted as a popular research method, and trade liberalization was a prominent feature of international trade at this stage. The continuous evolution of research hotspots showed epochal and cutting-edge characters.

\section{Analysis of Recent Hotspots of International Trade in Manufacturing}

To track the newest research hotspots, the keywords co-occurrence analysis in the past 180 days were carried out. The frontier research in the 180 days before April 18, 2020, was identified, as shown in Table 6. Taking advantage of Usage 180 function in CiteSpace, according to the number of full-text visits or full-text downloads in the past 180 days, it reflected the high-frequency keywords of international trade in manufacturing. China was the most frequently used keyword recently, with a total frequency of 21 times. As a major manufacturing country and trading country, China attracted the attention of many scholars. In

Table 6. The lists of high frequency keywords in recent 180 days (Top 10).

\begin{tabular}{cccc}
\hline Ranking & Count & Year & Keywords \\
\hline 1 & 21 & 2011 & china \\
2 & 12 & 2011 & CO $_{2}$ emission \\
3 & 11 & 2015 & adjustment \\
4 & 10 & 2012 & agriculture \\
5 & 10 & 2013 & behavior \\
6 & 10 & 2010 & agreement \\
7 & 9 & 2012 & agglomeration \\
8 & 9 & 2012 & business \\
9 & 7 & 2013 & asia \\
10 & 7 & 2010 & bilateral trade \\
\hline
\end{tabular}


addition, high-frequency keywords also included carbon dioxide emissions, reflecting the academic community's increasing emphasis on the environment. International trade was in a dynamic situation, so it was normal to adjust timely to respond to changes in the internal and external environment. What was surprising that agriculture became a recent research focus in this field. Simultaneously, specific behaviors and policy agreements helped to promote the systematic development of international trade in manufacturing.

\section{Knowledge Structure of International Trade in Manufacturing}

Co-citation analysis means that if the two documents appear in the bibliography of the third cited document, the two documents form a co-citation relationship (Small, 1973). Co-citation analysis reflects the main problems and methods in the research of academic papers and the main contributions it has made. It is a concise summary of the main research viewpoints and is used here as a key indicator of document clustering analysis. Cluster analysis reveals the knowledge structure in a certain field and reflects important scholars and classical works of literature.

The network of international trade in manufacturing included 156 nodes, 255 links and 23 clusters. The smaller and non-main clusters were removed, and finally, 8 core clusters were obtained. The eight clusters are listed in Table 7, which contain 193 nodes, accounting for $83 \%$ of the entire network. The cluster was named according to the LLR algorithm, and the keyword named phrase tag of the clustering article is quoted (Chen, Ibekwe-Sanjuan, \& Hou, 2010). The name of the cluster was extracted from the keywords of the cited documents, but it did not fully represent the characteristics of the cluster. It still needed to be interpreted in detail in combination with the articles within the cluster. The label of Cluster 0 is f10 (Related JEL classifications), which was difficult to represent the characteristics of clustering. Through literature browsing within this cluster, f10 was renamed to trade liberalization, while the rest of the labels remained unchanged (Table 7). The silhouette values of the main clusters in the sustainable

Table 7. Major clusters of co-cited references.

\begin{tabular}{ccccc}
\hline Cluster ID & Size & Silhouette & Mean (year) & Lable (LLR) \\
\hline 0 & 23 & 0.976 & 2008 & trade liberalization (f10) \\
1 & 22 & 0.99 & 2016 & decomposition analysis \\
2 & 21 & 0.901 & 2006 & regional ecological footprint \\
3 & 20 & 0.957 & 2010 & trade facilitation platform (Tfp) \\
4 & 19 & 0.83 & 2011 & markups \\
5 & 13 & 0.897 & 2010 & exports \\
6 & 7 & 0.98 & 2008 & input-output model \\
7 & 5 & 0.93 & 2012 & consumption-based accounting \\
\hline
\end{tabular}


field of the manufacturing industry were between 0.8 and 1, which indicated that the homogeneity of inter-cluster was very high. Year indicated the average publication year of the cluster.

CiteSapce provides rich visual demonstrations when analyzing emerging trends and changes in the network. In Figure 5, the connection between the two nodes indicates that the two articles have been quoted together, and the node size indicates the frequency of citation. Different colors of nodes and connections distinguish different times respectively. In this paper, highly cited classical publications of each cluster were selected, which represented the knowledge base of a certain field. Frontier literature represented research hotspots and trends in a certain field, and represented current research status. Modularity $Q$ and mean Silhouette were used to evaluate the clustering effects of maps. The modularity of the overall network is used to evaluate the network modularity index. The larger the value, the better the clustering obtained by the network. Its value greater than 0.3 meant that the obtained network community structure was significant. The higher the mean silhouette value, the higher the homogeneity of the clustering, which reflected the consistency of the literature in the clustering. If the value was greater than 0.5 , the structure of the cluster was reasonable. The modularity of this network was 0.7753 and the mean silhouette value was 0.5853 , which indicated that the cluster of this network was of high reliability (Figure $5)$.

The research topic of Cluster 4 was markups. Hiroyuki explored that heterogeneous enterprises benefit from a large amount of trade in end products and intermediate products, thus improving productivity and markups (Kasahara \&

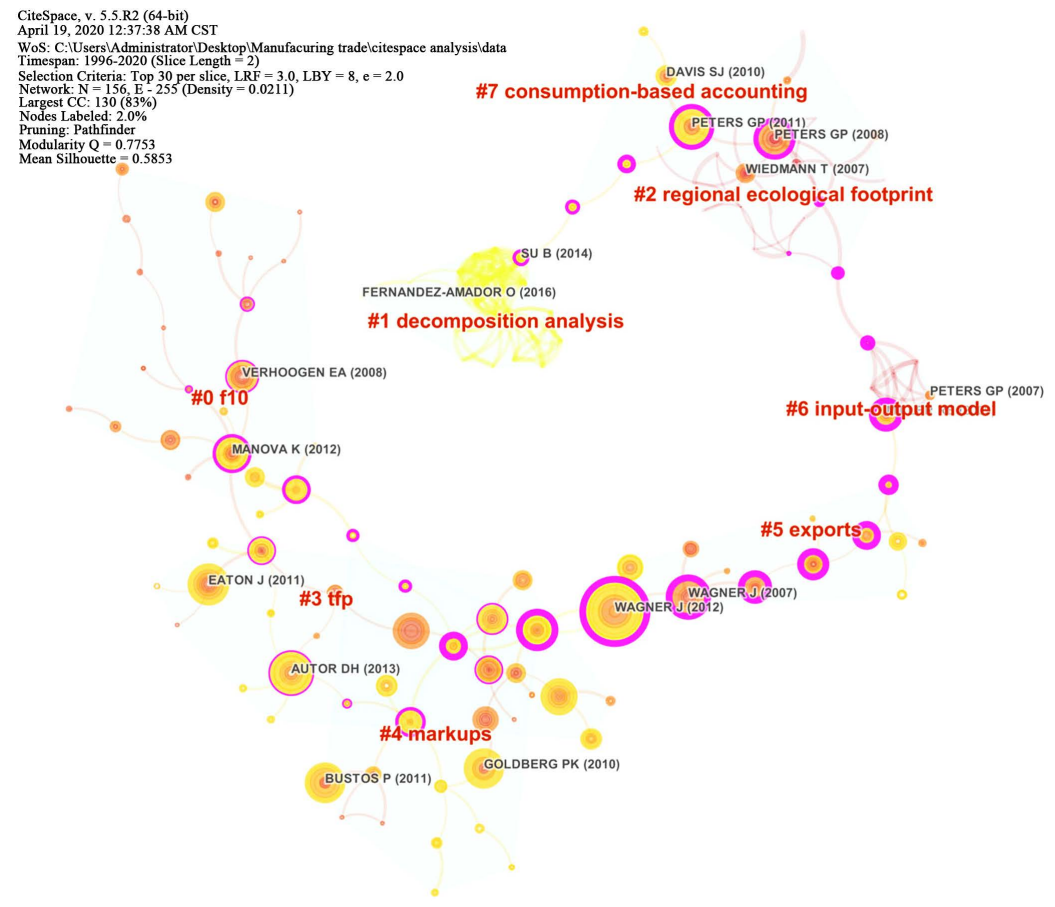

Figure 5. The knowledge map of co-citation. 
Lapham, 2013). Paula from another research perspective concluded that increased income from trade integration can promote exporters to upgrade technology (Bustos, 2011). Pinelopi provided empirical evidence for markups and gained huge benefits through imported inputs (Goldberg, Khandelwal, Pavcnik, \& Topalova, 2010). The above research also conformed to the theory of comparative advantage and factor endowment.

The research topic of Cluster 5 was export. Wagner was an active research contributor in this field. Wagner, through a retrospective analysis of the literature, focused on the relationship between international trade of manufacturing or service companies and corporate performance in empirical research (Wagner, 2012). Another of his articles explored the relationship between exports and productivity from the enterprise level, concluded that exports promote economic growth (Wagner, 2007). A literature review was used to analyze the heterogeneity of enterprises in international trade in a multi-dimensional way, to expand the new theoretical development of the heterogeneity of companies and to inspect the prediction based on theory, including the dimension of enterprise export market (Bernard, Jensen, Redding, \& Schott, 2012).

Cluster 0 and Cluster 3 contained different research emphasis. There was a large number of literature on those clusters, which were mainly focused on two aspects: trade liberalization and trade facilitation. Scholars were more inclined to go deep into the enterprise level, for example, Kalina constructed a heterogeneous enterprise model to restrict credit and hinder the mechanism of global trade (Manova, 2012). Jonathan used the model of enterprise heterogeneity and exported participation to evaluate the impact on market share under different market access conditions (Eaton, Kortum, \& Kramarz, 2011). In terms of trade liberalization, the relationship between price, quality, factory scale and labor attracted extensive attention of scholars (Kugler \& Verhoogen, 2011; Manova \& Zhang, 2012; Verhoogen, 2008), while academia was full of interest in manufacturing enterprises in developing countries.

The average publication year of Cluster 6 was 2008, the average publication year of Cluster 1 was 2016. The decomposition analysis of Cluster 1 was the evolution of the input-output analysis of Cluster 6 in the environmental application. Ronald took the lead in putting forward input-output analysis, which was widely used in the field of international trade (Miller \& Blair, 2009). Since the 1990s, with economic globalization and the growth of international trade, energy and emission research technologies developed rapidly. Structural decomposition analysis based on environmental input and output became the mainstream research method (Meng et al., 2018; Peters, Weber, Guan, \& Hubacek, 2007; Su \& Ang, 2014).

Cluster 2 and Cluster 7 referred to environmental factors in international trade and be analyzed from the perspective of sustainability. In the cluster of regional ecological footprint, scholars analyzed the impact and factors of carbon emission footprint. Peters believed that emissions from trade may have a significant impact on the participation and effectiveness of global climate policies, and 
proposes policies to reduce the impact of trade on global climate (Peters \& Hertwich, 2008). You pointed out that international trade can transfer environmental impacts from country to country and lead to an increase in global greenhouse gas emissions (Li \& Hewitt, 2008). Thomas proposed that production formula, land and energy use and emissions need to be considered in multi-regional, multi-sectoral and multi-directional trade models (Wiedmann, Lenzen, Turner, \& Barrett, 2007). The classic literature of Cluster 7 made an in-depth analysis and discussion by consumption-based accounting quantification on carbon emission framework (Kanemoto, Lenzen, Peters, Moran, \& Geschke, 2012), carbon emission growth (Davis \& Caldeira, 2010) and carbon emission accounting employing, and put forward constructive suggestions for the follow-up research on carbon emission in international trade.

\section{Emerging Trends of International Trade in Manufacturing}

The research frontier refers to the most advanced, up-to-date and promising research topics or research fields in scientific research. Identification and tracking of research frontiers can provide researchers with the latest evolution of research in this field, which is conducive to better grasp the development trend of this field and predict future research trends. This study made an in-depth investigation of the works of literature published in the past 25 years by burst-detection. Burst-detection is a computational technique used to discover events and other types of mutations (Kleinberg, 2002), which usually indicates that a potentially interesting issue has attracted a lot of attention in a short period. Burst-detection has two attributes, one is the intensity of the burst, the other is the duration of the burst. Based on the burst-detection from the previous articles of international trade in manufacturing, the results are listed in Table 8.

As shown in Table 8, the research by Timmer and Johnson of Cluster 5 attracted the interest of scholars in the field in the most recent period, and lasted for as long as 3 years. The research of Timmer was of guiding significance to the use of the world input-output database (Timmer, Dietzenbacher, Los, Stehrer, \& de Vries, 2015). Johnson examined the changes in prices within exporters between different destinations (Johnson, 2012). Scholars in international trade seemed to prefer to export trade. Cluster 4 occupied the highest proportion in the most cutting-edge literature. Therefore, markups was currently the most concerned topic of international trade in manufacturing. Goldberg and Topalova focused on how to improve the markups of emerging market India. The former explored the relationship between import intermediate input and domestic product growth (Goldberg et al., 2010), while the latter studied trade liberalization and enterprise productivity (Khandelwal \& Topalova, 2011). Other influential scholars analyzed the relationship between welfare and price, trade reform (Loecker, Goldberg, Khandelwal, \& Pavcnik, 2012) and productivity (Hallak \& Sivadasan, 2013; Lileeva \& Trefler, 2010) in-depth to seek the research paradigm of markups maximization. Khandelwal used price and quantity information to 
Table 8. Articles published with citation bursts (Latest time).

\begin{tabular}{|c|c|c|c|c|c|}
\hline Author & Title & Strength & Duration & Cluster\# & $1996-2020$ \\
\hline TIMMER MP & $\begin{array}{l}\text { An Illustrated User } \\
\text { Guide to the World } \\
\text { Input-Output Database: } \\
\text { the Case of Global } \\
\text { Automotive Production }\end{array}$ & 3.8169 & $2017-2020$ & 5 & \\
\hline JOHNSON RC & $\begin{array}{l}\text { Trade and prices with } \\
\text { heterogeneous firms }\end{array}$ & 3.4961 & $2017-2020$ & 5 & \\
\hline GOLDBERG PK & $\begin{array}{l}\text { Imported Intermediate } \\
\text { Inputs and Domestic } \\
\text { Product Growth: } \\
\text { Evidence from India }\end{array}$ & 6.0741 & 2016-2018 & 4 & \\
\hline KHANDELWAL A & $\begin{array}{c}\text { The Long and Short (of) } \\
\text { Quality Ladders }\end{array}$ & 5.755 & $2017-2018$ & 0 & \\
\hline DE LJ & $\begin{array}{l}\text { Prices, Markups, } \\
\text { and Trade Reform }\end{array}$ & 5.2184 & 2017-2018 & 4 & \\
\hline HALLAK JC & $\begin{array}{l}\text { Product and process } \\
\text { productivity: Implications } \\
\text { for quality choice and } \\
\text { conditional exporter premia }\end{array}$ & 4.7797 & $2017-2018$ & 4 & \\
\hline TOPALOVA P & $\begin{array}{l}\text { Trade Liberalization } \\
\text { and Firm Productivity: } \\
\text { The Case of India }\end{array}$ & 4.2537 & 2016-2018 & 4 & \\
\hline LILEEVA A & $\begin{array}{c}\text { Improved Access to } \\
\text { Foreign Markets Raises } \\
\text { Plant-level Productivity... } \\
\text { For Some Plants }\end{array}$ & 3.2872 & 2016-2017 & 4 & \\
\hline
\end{tabular}

estimate the quality of products exported to the United States, and explained the heterogeneous impact of low wage competition on employment and output in the US manufacturing industry (Khandelwal, 2010). To sum up, exploring international trade benefits from the perspective of industries and enterprises, using world input-output analysis, paying attention to the quality of manufactured goods, and focusing on the export trade market would become new trends of international trade in manufacturing.

\section{Conclusion}

In this paper, bibliometrics based on knowledge map was adopted to summarize the research characteristics and basic situation in the field of international trade in manufacturing, to describe the evolution of the field, and on this basis to explore the future development trends of international trade in manufacturing. CiteSpace software was used to analyze 1027 articles in the field from 1996 to 2020 , including core journals, core authors, core regions, discipline distribution, keywords co-occurrence, and knowledge map of literature co-citation. The main research results could be presented as follows:

- The highly cited core journals in this field were mainly concentrated in the 
economic field, and the research results were of high quality. Most authors were individuals or small groups, and academic communications between authors were not close. The core areas of high productivity were distributed in North America, Europe, Asia and Australia. The United States topped the list with 296 articles, while the British International Economic Research Agency was the core research institution in the world. In terms of discipline distribution, the field had shifted from business and economics to international relations and business, showing a trend of interdisciplinary development.

- The co-occurrence of keywords of international trade in manufacturing proved that it mainly focused on the level of enterprises and industries, paid attention to enterprise productivity or influencing factors, and how to realize growth and maintain export advantages. In addition, the number of research hotspots had undergone rarely clusters to loose and diverse clusters. The co-occurrence analysis of keywords for nearly 180 days indicated that China attracted more and more scholars' attention. Carbon dioxide emission became a new research hotspot under the concept of sustainability.

- The results of document co-citation showed that international trade in manufacturing can be subdivided into eight mainstream research fields, namely, trade liberalization, decomposition analysis, regional ecological footprint, trade facilitation platform, markups, export, input-output model and consumption-based accounting. Through further analysis of the above knowledge structure, we can master the development track of international trade core areas in manufacturing and lay a foundation for exploring new development trends.

- As a result of burst-detection, the research in the field of international trade markups, world input-output analysis, quality improvement and export market will become emerging trends.

This paper through the quantitative analysis of literature characteristics and cited data, comprehensively grasped the current situation, frontier, hotspots and trends of international trade in manufacturing over the 25 years. To provide references and suggestions for scholars concerned in this field and decision-makers of governments and enterprises, and to make contributions for further in-depth research, there were still some shortcomings in this article. Only the core data set of Web of Science was selected in this study, and some research documents may be omitted. Future research can extend the data set from Scopus or Pubmed.

\section{Conflicts of Interest}

The authors declare no conflicts of interest regarding the publication of this paper.

\section{References}

Bernard, A. B., Jensen, J. B., Redding, S. J., \& Schott, P. K. (2012). The Empirics of Firm Heterogeneity and International Trade. Annual Review of Economics, 4, 283-313. 
https://doi.org/10.1146/annurev-economics-080511-110928

Bustos, P. (2011). Trade Liberalization, Exports, and Technology Upgrading: Evidence on the Impact of MERCOSUR on Argentinian Firms. American Economic Review, 101, 304-340. https://doi.org/10.1257/aer.101.1.304

Chen, C., Ibekwe-Sanjuan, F., \& Hou, J. (2010). The Structure and Dynamics of Co-Citation Clusters: A Multiple-Perspective Co-Citation Analysis. Journal of the American Society for Information Science and Technology, 61, 1386-1409. https://doi.org/10.1002/asi.21309

Chen, X. P., \& Shao, Y. C. (2017). Trade Policies for a Small Open Economy: The Case of Singapore. World Economy, 40, 2500-2511. https://doi.org/10.1111/twec.12555

Cherniwchan, J., Copeland, B. R., \& Taylor, M. S. (2017). Trade and the Environment: New Methods, Measurements, and Results. Annual Review of Economics, 9, 59-85. https://doi.org/10.1146/annurev-economics-063016-103756

Davis, S. J., \& Caldeira, K. (2010). Consumption-Based Accounting of $\mathrm{CO}_{2}$ Emissions. Proceedings of the National Academy of Sciences, 107, 5687-5692.

https://doi.org/10.1073/pnas.0906974107

Eaton, J., Kortum, S., \& Kramarz, F. (2011). An Anatomy of International Trade: Evidence from French Firms. Econometrica, 79, 1453-1498. https://doi.org/10.3982/ECTA8318

Frei, F., Loder, A., \& Bening, C. R. (2018). Liquidity in Green Power Markets: An International Review. Renewable \& Sustainable Energy Reviews, 93, 674-690.

https://doi.org/10.1016/j.rser.2018.05.034

Garfield, E. (2006). The History and Meaning of the Journal Impact Factor. JAMA: the Journal of the American Medical Association, 295, 90-93. https://doi.org/10.1001/jama.295.1.90

Goldberg, P. K., Khandelwal, A. K., Pavcnik, N., \& Topalova, P. (2010). Imported Intermediate Inputs and Domestic Product Growth: Evidence from India. The Quarterly Journal of Economics, 125, 1727-1767. https://doi.org/10.1162/qjec.2010.125.4.1727

Hallak, J. C., \& Sivadasan, J. (2013). Product and Process Productivity: Implications for Quality Choice and Conditional Exporter Premia. Journal of International Economics, 91, 53-67. https://doi.org/10.1016/j.jinteco.2013.05.001

Johnson, R. C. (2012). Trade and Prices with Heterogeneous Firms. Journal of International Economics, 86, 43-56. https://doi.org/10.1016/j.jinteco.2011.09.004

Kanemoto, K., Lenzen, M., Peters, G. P., Moran, D. D., \& Geschke, A. (2012). Frameworks for Comparing Emissions Associated with Production, Consumption, And International Trade. Environmental Science \& Technology, 46, 172-179. https://doi.org/10.1021/es202239t

Kasahara, H., \& Lapham, B. (2013). Productivity and the Decision to Import and Export: Theory and Evidence. Journal of International Economics, 89, 297-316. https://doi.org/10.1016/j.jinteco.2012.08.005

Khandelwal, A. (2010). The Long and Short (of) Quality Ladders. The Review of Economic Studies, 77, 1450-1476. https://doi.org/10.1111/j.1467-937X.2010.00602.x

Khandelwal, A., \& Topalova, P. (2011). Trade Liberalization and Firm Productivity: The Case of India. The Review of Economics and Statistics, 93, 995-1009. https://doi.org/10.1162/REST a 00095

Kleinberg, J. (2002). Bursty and Hierarchical Structure in Streams. Proceedings of the ACM SIGKDD International Conference on Knowledge Discovery and Data Mining, 7, 
91-101. https://doi.org/10.1145/775047.775061

Kugler, M., \& Verhoogen, E. (2011). Prices, Plant Size, and Product Quality. The Review of Economic Studies, 79, 307-339. https://doi.org/10.1093/restud/rdr021

Li, Y., \& Hewitt, C. N. (2008). The Effect of Trade between China and the UK on National and Global Carbon Dioxide Emissions. Energy Policy, 36, 1907-1914. https://doi.org/10.1016/j.enpol.2008.02.005

Lileeva, A., \& Trefler, D. (2010). Improved Access to Foreign Markets Raises Plant-Level Productivity...For Some Plants. The Quarterly Journal of Economics, 125, 1051-1099. https://doi.org/10.1162/qjec.2010.125.3.1051

Loecker, J., Goldberg, P., Khandelwal, A., \& Pavcnik, N. (2012). Prices, Markups and Trade Reform. Econometrica, 84, 445-510. https://doi.org/10.3386/w17925

Manova, K. (2012). Credit Constraints, Heterogeneous Firms, and International Trade. The Review of Economic Studies, 80, 711-744. https://doi.org/10.1093/restud/rds036

Manova, K., \& Zhang, Z. (2012). Export Prices across Firms and Destinations. The Quarterly Journal of Economics, 127, 379-436. https://doi.org/10.1093/qje/qjr051

Meng, J., Mi, Z., Guan, D., Li, J., Tao, S., Li, Y., \& Davis, S. J. (2018). The Rise of South-South Trade and Its Effect on Global $\mathrm{CO}_{2}$ Emissions. Nature Communications, 9, 1871. https://doi.org/10.1038/s41467-018-04337-y

Miller, R., \& Blair, P. (2009). Input-Output Analysis. Washington DC: Cambridge University Press. https://doi.org/10.1017/CBO9780511626982

Naudé, W., \& Szirmai, A. (2012). The Importance of Manufacturing in Economic Development: Past, Present and Future Perspectives. Merit Working Papers, 2012-041.

Nelson, D. R. (2019). Facing up to Trump Administration Mercantilism: The 2018 WTO Trade Policy Review of the United States. World Economy, 42, 3430-3437. https://doi.org/10.1111/twec.12875

Orden, D., \& Roberts, D. (2007). Food Regulation and Trade under the WTO: Ten Years in Perspective. Agricultural Economics, 37, 103-116.

https://doi.org/10.1111/j.1574-0862.2007.00238.x

Peters, G. P., \& Hertwich, E. G. (2008). $\mathrm{CO}_{2}$ Embodied in International Trade with Implications for Global Climate Policy. Environmental Science \& Technology, 42, 1401-1407. https://doi.org/10.1021/es072023k

Peters, G. P., Weber, C. L., Guan, D., \& Hubacek, K. (2007). China’s Growing $\mathrm{CO}_{2}$ Emissions: A Race between Increasing Consumption and Efficiency Gains. Environmental Science \& Technology, 41, 5939-5944. https://doi.org/10.1021/es070108f

Sanchez-Fung, J. R. (2016). Reviewing Trade Policy in China during the Transition to Balanced Economic Growth. World Economy, 39, 1934-1946.

https://doi.org/10.1111/twec.12476

Small, H. (1973). Co-Citation in the Scientific Literature: A New Measure of the Relationship between Two Documents. Journal of the American Society for Information Science, 24, 265-269. https://doi.org/10.1002/asi.4630240406

$\mathrm{Su}$, B., \& Ang, B. W. (2014). Input-Output Analysis of $\mathrm{CO}_{2}$ Emissions Embodied in Trade: A Multi-Region Model for China. Applied Energy, 114, 377-384.

https://doi.org/10.1016/j.apenergy.2013.09.036

Timmer, M. P., Dietzenbacher, E., Los, B., Stehrer, R., \& de Vries, G. J. (2015). An Illustrated User Guide to the World Input-Output Database: the Case of Global Automotive Production. Review of International Economics, 23, 575-605.

https://doi.org/10.1111/roie. 12178 
USTR (2018). USTR Issues Tariffs on Chinese Products in Response to Unfair Trade Practices.

https://ustr.gov/about-us/policy-offices/press-office/press-releases/2018/june/ustr-issue s-tariffs-chinese-products

Vaubourg, A. G. (2016). Finance and International Trade: A Review of the Literature. Revue D Economie Politique, 126, 57-87. https://doi.org/10.3917/redp.261.0057

Verhoogen, E. A. (2008). Trade, Quality Upgrading, and Wage Inequality in the Mexican Manufacturing Sector. Quarterly Journal of Economics, 123, 489-530.

https://doi.org/10.1162/qjec.2008.123.2.489

Wagner, J. (2007). Exports and Productivity: A Survey of the Evidence from Firm-Level Data. The World Economy, 30, 60-82.

https://doi.org/10.1111/j.1467-9701.2007.00872.x

Wagner, J. (2012). International Trade and Firm Performance: A Survey of Empirical Studies Since 2006. Review of World Economics, 148, 235-267. https://doi.org/10.1007/s10290-011-0116-8

Wiedmann, T., Lenzen, M., Turner, K., \& Barrett, J. (2007). Examining the Global Environmental Impact of Regional Consumption Activities-Part 2: Review of Input-Output Models for the Assessment of Environmental Impacts Embodied in Trade. Ecological Economics, 61, 15-26. https://doi.org/10.1016/j.ecolecon.2006.12.003

Zhang, X. F. (2017). Trade Policy Review for China: The World's Top Exporter with “New Normal” Economic Growth. World Economy, 40, 2491-2499.

https://doi.org/10.1111/twec.12569 